\title{
Blackout i found poetry \\ Od notatki i ,poezji z odzysku” do interpretacji tekstów o II wojnie światowej
}

\author{
Blackout and found poetry \\ From a note and "found poetry" to the interpretation \\ of texts about World War II
}

Summary: The author offers to use the creative activities of blackout poetry and found poetry to interpret works dealing with the subject of the Holocaust. She presents a detailed scheme of applying this form of work during lessons with students. She argues that such a solution can be an enrichment of traditional interpretation, it also allows to stimulate the creativity of students and engage them in the didactic process.

Keywords: blackout poetry, found poetry, poem, didactics of literature, Holocaust

Poezja ,znaleziona” (found poetry), „,kreatywna”, „,wykreślona”/”wymazana” (blackout poetry), ,z odzysku”, a także ,negatywna”. Pod tymi określeniami ${ }^{1}$ kryją się działania twórcze związane z bardziej lub mniej przypadkową pracą z tekstem publicystycznym lub epickim (czasem także dramatycznym), mające na celu przygotowanie wypowiedzi przypominającej swoją strukturą utwór poetycki. Przegląd (głównie amerykańskich) propozycji wykorzystania tej kreatywnej pracy ze słowami jako metody dydaktycznej zmierza do udowodnienia jej

${ }^{1}$ Choć wymienione terminy nie zawsze są traktowane synonimicznie, mają z sobą wiele wspólnego, a kryjące się za nimi idee najczęściej stanowią kompilację rozmaitych pomysłów i rozwiązań. Idąc tym tropem, należy uznać, że poezja wykreślona z tekstu (blackout poetry) po przepisaniu na kartkę staje się poezją znalezioną (found poetry). 
wartości w kontekście interpretacji utworów podejmujących temat Zagłady — na przykładzie wierszy „znalezionych” w jednym z Medalionów Zofii Nałkowskiej.

\section{Twórcza i przemyślana notatka}

$\mathrm{Na}$ poświęconym nauczaniu historii anglojęzycznym portalu „Facing History and Ourselves” ",znalezione wiersze” zostały zaprezentowane jako jedna z metod powtórzenia i usystematyzowania omówionych na lekcjach treści. Jak nietrudno się domyślić z charakteru ćwiczenia, „wiersz” rozumiany jest tu jako forma graficzna, a nie wypowiedź o charakterze lirycznym. Kolejność zaproponowanych działań nad jego powstaniem jest następująca:

1. Czytając poznane fragmenty podręcznika i teksty źródłowe oraz inne dostępne materiały, uczniowie tworzą listę znaczących słów, sformułowań i cytatów. Sugerujemy, aby każdy zgromadził od piętnastu do dwudziestu różnych pojęć i fraz, z których następnie będzie czerpał inspirację do komponowania swojego wiersza.

2. W drugim kroku uczniowie identyfikują temat i dobierają przesłanie związane z wybranym zakresem słownictwa. Mogą skorzystać ze swojej pomocy, inspirować się nawzajem.

3. Ponieważ „znalezione wiersze” opierają się tylko na słowach zaczerpniętych z tekstów wyjściowych, uczniowie dobierają dodatkowe wyrazy i wyrażenia $\mathrm{z}$ już przejrzanych źródeł.

4. W tym momencie uczniowie są już gotowi do tego, by ułożyć swoje wiersze. Mogą zapisać zgromadzone określenia na osobnych karteczkach, aby swobodnie układać je na papierze aż do momentu osiągnięcia satysfakcjonującego efektu. Warto podpowiedzieć młodym ludziom, że niedozwolone jest dodawanie własnych słów, ale mogą powtarzać słowa lub frazy tak często, jak im się podoba, albo zrezygnować ze swoich wcześniejszych wyborów.

5. Gdy wiersze są gotowe, trzeba się nimi podzielić. Chętni uczniowie mogą odczytać swoje utwory na głos. Można także pozwolić im na ciche czytanie i pisemne komentowanie prac kolegów.

6. Na koniec warto podyskutować o efektach zadania. Oto przykładowe pytania: Co powstałe wiersze mówią o przeanalizowanych materiałach? Co uderza nas w poznanych wypowiedziach? Co mają one ze sobą wspólnego? Czym się różnią? Co nas w nich zaskoczyło?³.

${ }^{2}$ Zob. https://www.facinghistory.org [data dostępu: 4.03.2019].

3 Przepis na notatkę w formie ,znalezionego wiersza” sformułowałam na podstawie wskazówek zawartych na stronie https://www.facinghistory.org/resource-library/teaching-strategies/ found-poems [data dostępu: 28.02.2019]. 
To samo ćwiczenie, jak sugerują autorzy portalu „Facing History and Ourselves", można przeprowadzić w małych grupach, choćby tylko w pierwszym i drugim kroku. Kładąc zaś nacisk na indywidualny odbiór poznawanych treści, warto zadbać o to, aby uczniowie potrafili uargumentować koncepcję swojego utworu. Proces komponowania wierszy pomaga bowiem powtórzyć i zsyntetyzować zawartość na przykład rozdziału podręcznika, ale sam wiersz nie zawsze ujawnia wszystkie ważne wnioski. Dlatego można poprosić uczniów o napisanie komentarza wyjaśniającego kształt ich poetyckiej wypowiedzi. Pytania pomocnicze to: Jakie jest przesłanie twojego wiersza? Gdzie możemy je dostrzec? Dlaczego wybrałaś/wybrałeś właśnie tę myśl?

Opisywana metoda dydaktyczna, ze względu na swoją atrakcyjność, zachęca do podzielenia się efektami pracy z szerszym niż tylko klasa gronem odbiorców. Uczniowie mogą zatem opublikować swoje wiersze w formie drukowanej lub na przykład na stronie internetowej szkoły. Innym rozwiązaniem jest zorganizowanie wieczoru poezji oraz zaproszenie uczniów z pozostałych klas, rodziców i nauczycieli. Publiczność warto poprosić o zadawanie autorom pytań na temat prezentowanych wierszy ${ }^{4}$.

\section{Wiersz znaleziony w gazecie Kreacja, inspiracja czy przypadek?}

Za twórcę współczesnej metody pisania wierszy na podstawie tekstów prasowych uznaje się Austina Kleona, autora książki Newspaper Blackout. Ten artysta i pisarz nie ukrywa, że miał swoich poprzedników, do których zaliczyć trzeba i Thomasa Jeffersona, i dadaistów na czele z Tristanem Tzarą.

Wskazówki Austina Kleona są proste i precyzyjne:

Weź gazetę.

Chwyć marker.

Znajdź artykuł.

Wykreśl słowa, zostawiając tylko te, które ci się podobają.

Wkrótce będziesz mieć wiersz ${ }^{5}$.

Pomysłodawca pracy z tekstami prasowymi dodaje ponadto, że wcale nie czyta wcześniej artykułu, ponieważ ,im bardziej traktuję gazetę jako surowy

\footnotetext{
${ }^{4}$ Zob. ibidem.

${ }^{5}$ A. Kleon: Newspaper Blackout. New York 2010, s. 157.
} 
materiał, a mniej jako gotowy tekst, tym lepsze są moje wiersze" ${ }^{\text {"6 }}$ Zachęca także do dzielenia się powstałymi na podstawie tekstów zamieszczonych w czasopismach utworami i podkreśla, że z pisania poezji warto uczynić przyjemność, rodzaj zabawy.

Inni propagatorzy tego rodzaju twórczości idą jeszcze dalej w doborze materiału wyjściowego, proponując teksty na opakowaniach produktów, menu, nekrologi, przepisy kulinarne, ulotki reklamowe, instrukcje czy listy rzeczy do zrobienia?.

Poezja wykreślona doczekała się nie tylko wielu stron w mediach społecznościowych, ale także periodyku on line „The Found Poetry Review" i cyklicznych konkursów. „New York Times” zaprasza do tworzenia wierszy składających się z maksymalnie piętnastu wyrazów na swojej stronie internetowej - wystarczy kliknąć wybrane słowa, aby otrzymać obraz kartki z zakreślonym na czarno pozostałym tekstem i swoim utworem na jasnym tle 9 .

Odmianą działań podejmowanych na tekstach artykułów prasowych jest praca $\mathrm{z}$ ich tytułami i nagłówkami. Najprostszą, propagowaną w dydaktyce już pod koniec XX wieku, metodą ich wykorzystania jest układanie historyjki, co zwykle wiąże się z dużą dawką śmiechu i zauważeniem inwencji słownej dziennikarzy ${ }^{10}$. W przypadku bardziej przemyślanego ćwiczenia, takiego jak odpowiedni dobór typu i tematyki gazet, uczniowie mogą z łatwością dostrzec i rozróżnić profil oraz światopogląd prezentowany w danym tytule prasowym ${ }^{11}$.

Dydaktyka zagraniczna proponuje, aby z tytułów także, metodą przypadkowego doboru, a później uzasadnionego układu, tworzyć wypowiedzi o charakterze poetyckim, czyli kondensującym treść i przesłanie ${ }^{12}$.

Strony z wierszami znalezionymi w innych tekstach są obecne także w polskojęzycznej przestrzeni Internetu ${ }^{13}$. Te nowo powstałe wypowiedzi bywają określane jako „kreatywna dekonstrukcja” lub „wiersze z odzysku” i definio-

${ }^{6}$ Ibidem, s. 160.

7 Zob. https://thewritepractice.com/what-is-found-poetry/ [data dostępu: 2.03.2019].

${ }^{8}$ Zob. http://www.foundpoetryreview.com/ [data dostępu: 2.03.2019].

9 Por. https://www.nytimes.com/interactive/2014/multimedia/blackout-poetry.html?mcubz= 3\&_r=0 [data dostępu: 1.03.2019].

${ }^{10}$ Tego typu zabawę proponowano na przykład w ramach projektu „Kreator”.

11 Takie ćwiczenie, rozwijające hasło „A to Polska właśnie”, przeprowadziłam z klasą licealną w Brzesku. Przyniosło ono bardzo dobre rezultaty i stało się impulsem do żywej dyskusji. Więcej na ten temat w: A. Kania: „Polak młody” na lekcjach języka polskiego. Edukacja polonistyczna a kształtowanie poczucia tożsamości narodowej. Kraków 2015, s. 245-246.

${ }^{12}$ Wskazówki dotyczące ułożenia wiersza z nagłówków prasowych zawiera poradnik na stronie amerykańskiego National Council of Teachers of English. https://secure.ncte.org/library/ NCTEFiles/Resources/Books/Sample/18488chap1.pdf [data dostępu: 1.03.2019], oraz strona czasopisma „Teach Magazine”. http://teachmag.com/archives/5539 [data dostępu: 1.03.2019].

${ }_{13}$ Zob. http://spisekpisarzy.pl/2016/01/kreatywna-dekonstrukcja-cwiczenie-na-mocniejszepioro.html [data dostępu: 3.02.2019]. 
wane na przykład w następujący sposób: ,[...] forma literacka, polegająca na wyłuskaniu ciekawego doboru słów z jednej strony powieści przypadkowego autora" ${ }^{14}$, co, jak widać, nie wyjaśnia w pełni istoty podejmowanego działania. W stronę ludycznej czynności kierują nas także zachęty typu: ,[...] jeśli interesują Cię eksperymenty literackie, kultura remixu, recykling lub zwyczajnie nudzisz się na zajęciach lub w pracy — przyjdź i zobacz, jak z ulotek i studenckich kserówek tworzy się coś wartościowego"15.

Zdarzają się jednak ciekawe uzasadnienia twórczych działań na cudzym tekście:

Negatyw to odwrotność pozytywu, czyli oryginału. Zaciemniamy tekst, a następnie wpuszczamy tylko prześwity, wiązki światła, dzięki którym ujawnia się zupełnie nowy obraz. Nowy wiersz z cudzych słów. Poezja negatywna działa jak od-i-za-słonięcie. Jest ciągle powracającym kontrastem, za sprawą którego rozbłyska wiersz ${ }^{16}$.

Blogi nauczycieli języka polskiego i angielskiego jako ojczystego to źródło podpowiedzi, jak pracować $\mathrm{z}$ uczniami $\mathrm{w}$ różnym wieku na tekstach powieści i wyczarowywać $\mathrm{z}$ nich nie tylko poetyckie, ale także plastyczne $\operatorname{arcydzieła}{ }^{17}$ :

Uczniowie tworzyli z kartek starych książek („Lew, czarownica i stara szafa” oraz „Głowa na tranzystorach”) takie zabawne formy poetyckie i kolaże. Zabawa polega na tym, aby na kartce ze starej książki czy gazety zaciemnić wszystkie słowa, które nam się nie podobają, a zostawić te, które są nam potrzebne do tworzenia wiersza ${ }^{18}$.

Wydaje się, że ze względu na szansę wyzwolenia kreatywności uczniów oraz zwrócenia ich uwagi na język metoda blackout poetry sprzyja kształceniu literackiemu i nawiązywaniu bliższego kontaktu ze słowami dla nas znaczącymi. Biorąc pod uwagę jej walory, dobrze ujęte w sformułowaniu na stronie „Power Poetry”: ,[...] jest jak poszukiwanie skarbów, ponieważ znajdujesz zaszyfrowane

${ }^{14}$ Ibidem.

${ }_{15}$ Por. https://dzialajwarte.wordpress.com/2015/12/09/blackout-poetry-po-polsku/ [data dostępu: 1.03.2019].

$16 \mathrm{http}: / /$ poezjanegatywna.tumblr.com/ [data dostępu: 4.03.2019].

${ }_{17}$ Praca nauczyciela krok po kroku została opisana po angielsku na przykład na stronie https://www.scholastic.com/teachers/blog-posts/john-depasquale/blackout-poetry/ [data dostępu: 1.03.2019], a efekty pracy na lekcji języka polskiego w gimnazjum — na stronie https://polonistkaprzytablicy.blogspot.com/2017/03/wiersze-z-odzysku-na-dzien-kobiet.html?fbclid=Iw AR2hWdcFkPlhnrQoMyCsUu8q4iu7_zBBINYyphBX0zMRvy66YSc1bqALr3Y [data dostępu: 1.03.2019].

${ }^{18} \mathrm{http} / /$ biblioteki-szkolne.blogspot.com/2018/04/poezja-negatywna-blackout-poerty.html [data dostępu: 2.03.2019]. 
znaczenia i ukryte przesłania w najmniej spodziewanych miejscach"19, szkoda stosować ją w nieprzemyślanych sytuacjach, nie dbać o spójność i logikę powstałych tekstów, traktować jak zapychacz czasu i nazywać ,poezją z odzysku”.

\title{
W stronę pogłębionej interpretacji tekstu
}

\begin{abstract}
Nadawca wiadomości nigdy nie może w pełni poznać mentalności swojego odbiorcy...

Każdy wiersz to wiadomość, inna dla każdego czytelnika.
\end{abstract}

James Gleick The Information ${ }^{20}$

W naszym zabieganym świecie uważne zatrzymanie się nad świadectwem czasów pogardy i znalezienie w nim przesłania dla siebie to, jak piszą autorzy strony „Facing History and Ourselves”, okazanie szacunku ofiarom i pełne empatii respektowanie trudnych doświadczeń ${ }^{21}$. Interpretacja wielopoziomowego utworu o II wojnie światowej w warunkach lekcyjnych często sprowadza się do historycznoliterackiego wykładu i upowszechnienia skostniałych przekonań na jego temat. Tymczasem, zamiast „opowiedzieć” wszystkie relacje zawarte na przykład w Medalionach, lepiej przyjrzeć się uważniej jednej z nich i dokonać jej pogłębionej interpretacji.

Na podstawie silnie działających na emocje i niezwykle twórczych warsztatów, łączących metody blackout i found poetry, a przeprowadzonych na podstawie tekstu Jenny Robertson Inside the Sewing Machine Drawer ${ }^{22}$ dla studentów Wydziału Polonistyki przez doktor Karen Shawn z Nowego Jorku w ramach projektu Ministerstwa Nauki Szkolnictwa Wyższego Akademickie Centrum Kreatywności w maju 2015 roku $^{23}$, opracowałam własną koncepcję zajęć z wy-

$19 \mathrm{https} / /$ www.powerpoetry.org/actions/5-tips-creating-blackout-poetry [data dostępu: 3.03.2019].

${ }^{20} \mathrm{http}: / /$ tumblr.austinkleon.com/post/15863189174 (tłumaczenie własne) [data dostępu: 3.02.2019].

${ }^{21}$ Zob.https://www.facinghistory.org/sites/default/files/Creating_a_Found_Poem_1.pdf[data dostępu: 3.03.2019]. W pliku znajdziemy szczegółowe wskazówki do pracy nad wierszem na podstawie świadectw osób ocalałych z Holokaustu. W dużej mierze są one podobne do sposobu tworzenia notatki z pewnej partii materiału, co opisałam w pierwszej części artykułu.

${ }_{22}$ J. Robertson: From the Volga ... to the Clyde. Glasgow 2014, s. 18-24.

${ }^{23}$ Pewne aspekty warsztatów Karen Shawn opisał Maciej Pabisek w artykule: M. Pabisek: Między kontynentami. Od inspiracji metodologicznej amerykańskiej badaczki Karen Shawn po praktyczna realizację w polskim liceum. W: Twórcze praktyki polonistyczne. Red. A. Janus-Sitarz. Kraków 2015, s. 261-273. Przedstawiony przeze mnie sposób wykorzystania prezentowa- 
korzystaniem relacji Przy torze kolejowym z tomu Medaliony Zofii Nałkowskiej $^{24}$. Moim działaniom przyświecały uwagi amerykańskiej badaczki, że intencją szukania wiersza w innym tekście jest zapewnienie czytelnikowi szansy na emocjonalnie zaangażowaną reakcję wobec tego tekstu oraz pozwolenie mu na indywidualną interpretację — skupienie się na tym aspekcie utworu, który do niego przemawia najsilniej.

Uznając, że wielowarstwowy tekst dotyczący Zagłady nie może się pojawić na lekcji bez wcześniejszego przygotowania uczniów do jego odbioru, przeprowadzałam dwugodzinne warsztaty w klasach maturalnych. Uczniowie ci byli w trakcie omawiania literatury poświęconej doświadczeniu II wojny światowej. W przypadku nauczycieli polonistów oraz studentów filologii polskiej — w ramach stworzenia odpowiedniej atmosfery — jako wprowadzenie do oryginalnej interpretacji utworu Zofii Nałkowskiej proponowałam obejrzenie kilkunastominutowego filmu o losach polskiej Żydówki Teofili Silberring ${ }^{25}$.

Trzeba mocno podkreślić, że nie każdy utwór literacki daje jednakowe szanse odbiorcy na znalezienie w nim własnego wiersza, dlatego tekst do pracy w ten sposób należy bardzo starannie wybierać ${ }^{26}$.

Przykładowy przepis na stworzenie wiersza - interpretacji utworu prozatorskiego wygląda następująco ${ }^{27}$ :

1. Przeczytaj uważnie tekst. Wyróżnij lub podkreśl słowa i wyrażenia, które uważasz za szczególnie ważne, poruszające lub interesujące. Mogą one odzwierciedlać twoje emocje bądź uczucia i działania osoby mówiącej w tekście. Możesz „znaleźć” swój wiersz na jednej stronie albo przeczytać cały utwór, aby odczytać sens i znaczenie, których potrzebujesz.

2. Spróbuj skoncentrować się na jednym aspekcie tekstu (temat, scena, bohater, przesłanie). Nie streszczaj całej opisanej historii.

3. Czarnym markerem zakreśl słowa i zdania, których nie wykorzystasz. Przeczytaj ponownie fragmenty, które zostały, i wyeliminuj zbędne wyrazy. Tutaj: „mniej znaczy więcej”.

nych tu wartościowych metod interpretacji tekstu wychodzi poza propozycje autora i częściowo $\mathrm{z}$ nimi polemizuje.

${ }^{24}$ Warsztaty przeprowadzałam kilkukrotnie w latach 2015-2018 w klasach III LO, dla nauczycieli języka polskiego oraz dla studentów filologii polskiej Uniwersytetu Jagiellońskiego i Uniwersytetu Wrocławskiego.

${ }^{25}$ Film jest dostępny polskiej wersji językowej na stronie http://www.centropa.org/node/ 60518 [data dostępu: 8.03.2019].

${ }^{26}$ Polonistki, uczestniczki prowadzonych przeze mnie warsztatów, pracowały z powodzeniem metodą blackout i found poetry z opowiadaniami Tadeusza Borowskiego oraz opowiadaniami Brunona Schulza. Także w Kamieniach na szaniec Aleksandra Kamińskiego znajdziemy odpowiednie fragmenty.

${ }_{27}$ Przepis ten, łączący ideę blackout i found poetry, to kompilacja sugestii z przywołanych w artykule amerykańskich stron internetowych, wskazówek Karen Shawn oraz moich własnych przemyśleń. 
4. Popatrz na całość i zdecyduj, czy widzisz jakieś słowa, które chcesz powtórzyć, aby wzmocnić swoją wypowiedź.

5. Nie dodawaj żadnych słów od siebie, nie zmieniaj znaczenia tych z analizowanego utworu.

6. Przepisz tekst na czystą kartkę tak, aby wyglądał jak wiersz. Zwróć szczególną uwagę na rytm i długość wersów. Zastosuj funkcjonalnie wielkie litery i znaki interpunkcyjne, podziel tekst na strofy lub zachowaj jego ciągłość. Pamiętaj, że to Ty decydujesz o kształcie (treści i formie) nowo powstającego utworu.

7. Dołącz tytuł - oryginału lub własny. Zanotuj tytuł i autora wyjściowego tekstu.

Uczestnicy moich zajęć pracowali w taki właśnie sposób. Otrzymawszy dwie strony z tekstu Przy torze kolejowym, zostali poproszeni o jego uważne przeczytanie, a następnie podkreślenie szczególnie znaczących słów lub fraz. Trzecia lektura, tym razem zaznaczonych fragmentów, miała polegać na dalszej eliminacji i pozostawieniu tylko tylu wyrazów, aby, po zapisaniu ich w formie wiersza, ostatecznie zmieściły się na jednej stronie A4. Niewykorzystaną część utworu należało zamalować na czarno (por. fot. 1.).

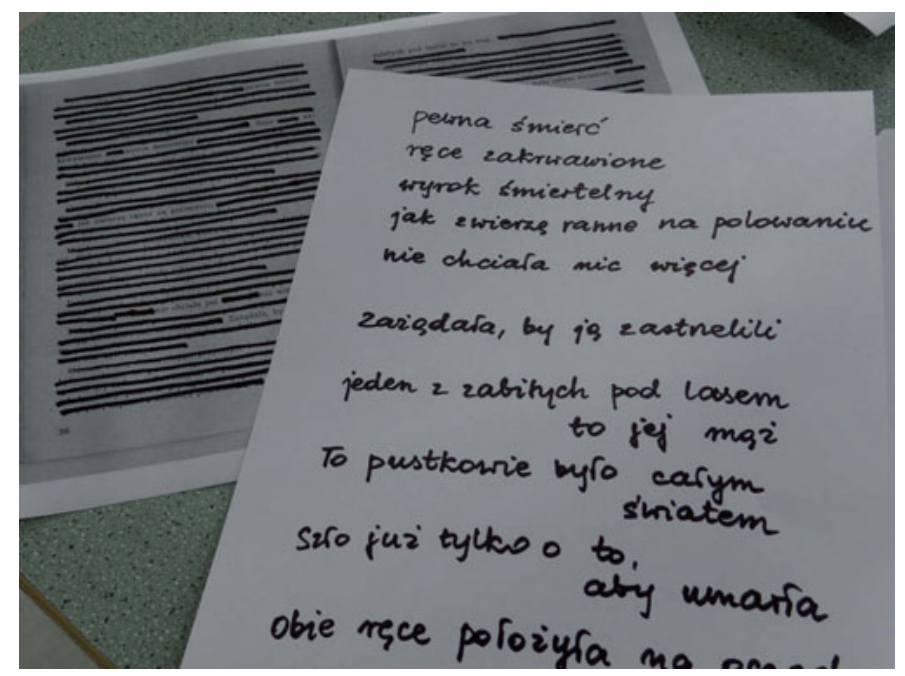

Fot. 1. Przykład pracy z tekstem Przy torze kolejowym

Z początkowej części opowiadania powstały na przykład takie wiersze:

Człowiek, który to widziat i który nie może

tego zrozumieć

Wiezieni dtugimi pociagami w zaplombowanych wagonach

do obozów zniszczenia 
Ogłuszajacy toskot

$W$ ciasnocie stloczonych ludzi, zgłodniałych, cuchnacych, brudnych

Zbita masa ludzka

Ci-zbyt stabi i lękliwi

Seria strzatów

Jechać spokojnie dalej w stronę wtasnej śmierci

Ona jedna została taka - ani żywa, ani umarła

Pustkowie

Ci, co leża pod lasem, nie żyją ${ }^{28}$.

Należy do umartych

mtoda kobieta

której ucieczka się nie udata

Wiezieni do obozów zniszczenia

niewielu się na taka ucieczkę ważyto

Wymagato to odwagi

$W$ ciasnocie stloczonych ludzi

wpadali pod koła

ginęli na miejscu

kobieta należała do odważnych

siedziała na zboczu rowu

— ani żywa, ani umarta.

Byta sama.

Do niej nie odezwat się nikt.

Wykreślanie/szukanie własnego „wiersza” w narracyjnym tekście o Zagładzie to nic innego jak docieranie do sedna przedstawianej historii i odnajdowanie jej własnej interpretacji. Skondensowana forma nowego tekstu, zapisanego jak wiersz, staje się odzwierciedleniem indywidualnego odczytania pierwotnego utworu. W celach edukacyjnych warto zwrócić uwagę uczniów na to, że pewne słowa czy frazy — jako najbardziej znaczące, dominujące, stanowiące słowa klucze - będą się w ich interpretacjach powtarzać. Natomiast to, czym poszczególne znalezione wiersze będą się od siebie różnić, wynika z osobowości, wrażliwości czy uważności poszczególnych odbiorców.

Najpoważniejszą trudnością w zadaniu okazał się brak umiejętności eliminowania słów, stąd w przepisywanych na osobną kartkę wierszach znajdowały się często całe frazy lub nawet zdania z pierwotnego tekstu. A może jednak były tak silnymi kotwicami, że nie sposób było ich pominąć?

${ }^{28}$ We wszystkich znalezionych wierszach zachowałam oryginalny układ oraz interpunkcję. 
O ile uwaga odbiorców pierwszej części Przy torze kolejowym skupiała się na odwadze związanej z ucieczką skazaną na porażkę oraz na samotności bohaterki, o tyle czytelnicy drugiej części (od słów Byt biaty dzień... do - No to dawaj pan mnie...) wyodrębniali dwa aspekty tekstu i przyglądali się im bliżej, przenosząc akcent na jeden lub drugi bądź łącząc je z sobą. Pierwszym była beznadziejna sytuacja rannej kobiety, drugim — zachowanie gromadzących się wokół niej ludzi. Oto przykłady:

Ręce zakrwawione

Wyrok śmiertelny

Jak zwierze ranne na polowaniu

Nie chciała już nic więcej

Zażadata, by ja zastrzelili

Jeden z zabitych pod lasem to jej mąz

To pustkowie byto calym światem

Szło już tylko o to, aby umarta

Obie ręce potożyta na oczach,

żeby już nic nie widzieć...

Czas byt wzmożonego terroru.

Wyrok śmiertelny na nia, uwięzty w jej kolanie.

Nie liczyła na pomoc.

Jak zwierze ranne na polowaniu.

Zażadała, by ja zastrzelili.

To pustkowie byto calym światem.

To jej maż tam leży zabity.

Szło juz tylko o to,

aby tak lub inaczej umarta.

Czas terroru pewna śmierć

Prosita... Odmówit

Wyrok śmiertelny jak gwóźdź

którym przybita do ziemi

Nie liczyla na pomoc

Zwierze ranne

Las, ucieczka, pustkowie

Strzelali z karabinu

Pomóc... nie ma sposobu

Szto o to, aby umarta

Ten wyrok śmiertelny na nia, uwięzły w jej kolanie tkwit tam jak gwóźdź, którym przybita była do ziemi 
Leżała pośród ludzi, ale nie liczyła na pomoc

Leżała jak zwierze ranne na polowaniu,

którego zapomniano dobić

Mówili tak... jakby jej już nie byto

Tak więc nikt nie zapragną zabrać jej stąd...

Nic takiego nie byto przewidziane

Szło już tylko o to, aby tak lub inaczej umarta

Byt biały dzień, czas wzmożonego terroru

Młody człowiek jeszcze stat, kupit jej

wyświadczyt przystuge

Leżała nie liczyła na pomoc

jak zwierzę którego zapomniano dobić

Nowi ludzie przystawali mówili jakby

wcale jej już nie byto

Znowu powiedziała by ja zastrzelili

wahali się...

Ustyszata glos mtodego

- No to dawaj mnie

Zakotwiczające się w umyśle odbiorcy słowa czy sformułowania $\mathrm{z}$ tekstu Przy torze kolejowym, jako z jednej strony znaczące, a z drugiej — spełniające wymogi powstającego wiersza, pozwoliły ponadto odkryć nieoczywisty walor poetyckości języka Medalionów, jego metafory i porównania.

Warto jeszcze wspomnieć o trzech interpretacjach utworu Zofii Nałkowskiej ze względu na ich oryginalną formę. Pierwsza jest niezwykle ascetyczna:

Krucze włosy

pod opuszczonymi powiekami

oczy zbyt czarne

nie żyja

nie żyja

na zboczu nasypu

drzemata

nieprzeparta sita

przerażenia

Druga jest wydobyciem skondensowanego sensu z prawie całego opowiadania:

Ani żywa, ani umarta.

Byta sama. Ale powoli zjawiali 
się ludzie. Stawali lękliwie,

patrzyli z oddalenia.

Rozmawiali z cicha, wzdychali.

Do niej nie odezwat się nikt.

Mówili tak, jakby jej już

nie byto.

I wreszcie godny uwagi jest pomysł oryginalnego zapisu wiersza — od dołu do góry, na kształt toru kolejowego wiodącego do miejsca przeznaczenia, wyznaczającego kres i nieunikniony los:

- Dawaj pan mnie...

Gtos tego młodego:

Jeden namawiat: - To ty sam

dwóch policjantów, wahali się

umarta

szło już tylko o to, aby tak czy inaczej

Jakby jej już nie byto

„strzelali", „, nie ma sposobu”

„, to jej mąż tam leży”, , uciekli"

ludzie przystawali, mówili:

nie chcieli

zażadała, by ja zastrzelili

policjanci podeszli - odeszli

stara wieśniaczka podeszła, zniknęta

zwierze ranne na polowaniu

nie liczyla na pomoc, jak

poprosiła, odmówit

wokót siebie nowe twarze

ręce zakrwawione, wyrok śmiertelny

biaty dzień, miejsce otwarte

Dyskusja o powstałych wierszach to naturalny element dalszego ciągu warsztatów.

Zapisane (najlepiej przy użyciu markerów) kartki formatu A4 warto wyeksponować na ścianie lub tablicy, a następnie zaprosić całą grupę do poczytania wypowiedzi koleżanek i kolegów (por. fot. 2.). Po lekturze dobrze jest poprosić uczestników o wysnucie wniosków i podkreślić kolorem na przykład najczęściej powtarzające się słowa lub frazy, czyli najbardziej znaczące fragmenty $\mathrm{w}$ tekście pierwotnym. Te z kolei należałoby zinterpretować: Jaką rzeczywistość przedstawiają? Jakie obserwacje/uczucia/niewypowiedziane refleksje się za nimi kryją? Co mówią o bohaterach? 


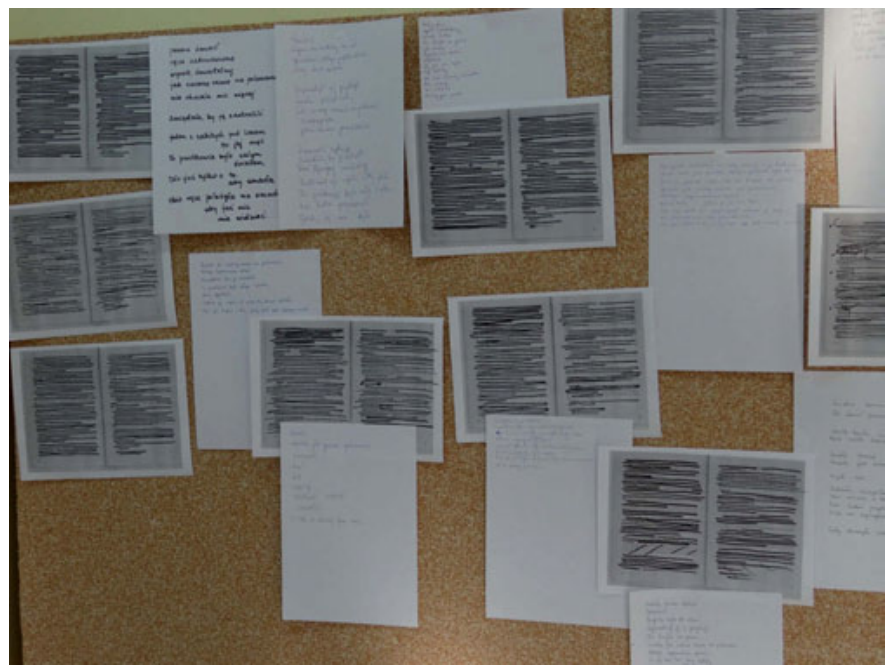

Fot. 2. Ekspozycja prac uczniów

Chętni lub wybrani autorzy mogą się podzielić swoim znalezionym wierszem i opowiedzieć o procesie dochodzenia do takiego, a nie innego odczytania utworu. Ważne wydaje się też poczynienie spostrzeżenia, że „wiersz” będzie zawsze bardziej oszczędny w słowach niż tekst epicki, ale to nie znaczy, że zawiera mniejszy ładunek emocji, bo te ukryte są na ogół między słowami, w niedopowiedzeniach i aluzjach.

Choć poezja miała już nie zaistnieć po Auschwitz, w osiemdziesiąt lat po wrześniu 1939 roku edukacja musi szukać nowych rozwiązań, by dotrzeć z antywojennym przesłaniem do współczesnego pokolenia młodych ludzi. Przedstawianie suchych faktów na lekcjach historii czy omawianie streszczeń utworów na lekcjach literatury nie przyniosą pożądanego rezultatu i nie wstrząsną uczniem tak mocno, aby dotarła do niego groza lat czterdziestych ubiegłego stulecia. Skupienie choć raz na jakiś czas uwagi nastolatków na rzeczywiście czytanym tekście, pozwolenie im na twórczą ekspresję, stworzenie przestrzeni do porównania poczynionych interpretacji i dyskusji nad nimi nie wymagają olbrzymich nakładów czasu i energii, a czynią wiele dobrego w kwestii zrozumienia przez młodzież hitlerowskiego systemu Zagłady i postaw ludzi, którzy znaleźli się w sytuacji granicznej.

Oprócz niewątpliwej wartości, jaką jest pogłębiona interpretacja tekstu i odczytanie go dla siebie z możliwością rzeczywistego porównania tego, jak odczytali go, również dla siebie, inni uczestnicy zajęć, metoda found poetry ma jeszcze tę zaletę, że pozwala niejako zabrać głos tym osobom, które najczęściej nie są aktywne podczas klasowych dyskusji czy pogadanek. Wielokrotnie zdarzyło się, że gdy po wywieszeniu kartek na tablicy przeglądałam powstałe teksty i szukałam najciekawszych rozwiązań, ich autorami okazywały się nieśmiałe 
uczennice lub byli nimi cisi uczniowie, mocno zdziwieni, że ich praca została dostrzeżona i uznana za wyjątkową.

Poezja wykreślona z gazet to, według przepisu Austina Kleona, świetna zabawa i sposób na rozwijanie wyobraźni. Nie ma jednak nic wspólnego z rozumieniem tekstu, który nie zostaje nawet przeczytany. Uważna lektura trudnego utworu literackiego polegająca na szukaniu w nim indywidualnie odbieranego przesłania, zapisywanego później jako przykład własnej twórczości, staje się natomiast wartościową metodą analizy i interpretacji.

\section{Bibliografia}

Kania A.: „Polak młody” na lekcjach języka polskiego. Edukacja polonistyczna a kształtowanie poczucia tożsamości narodowej. Kraków 2015.

Kleon A.: Newspaper Blackout. New York 2010.

Pabisek M.: Między kontynentami. Od inspiracji metodologicznej amerykańskiej badaczki Karen

Shawn po praktyczna realizację w polskim liceum. W: Twórcze praktyki polonistyczne. Red. A. Janus-Sitarz. Kraków 2015.

Robertson J.: From the Volga... to the Clyde. Glasgow 2014.

\section{Źródła internetowe}

http://biblioteki-szkolne.blogspot.com/2018/04/poezja-negatywna-blackout-poerty.html [data dostępu: 2.03.2019].

https://dzialajwarte.wordpress.com/2015/12/09/blackout-poetry-po-polsku/ [data dostępu:

1.03.2019].

http://poezjanegatywna.tumblr.com/ [data dostępu: 4.03.2019].

https://polonistkaprzytablicy.blogspot.com/2017/03/wiersze-z-odzysku-na-dzien-kobiet.html?fbcl id=IwAR2hWdcFkPlhnrQoMyCsUu8q4iu7_zBBINYyphBX0zMRvy66YSc1bqALr3Y [data dostępu: 1.03.2019].

https://secure.ncte.org/library/NCTEFiles/Resources/Books/Sample/18488chap1.pdf [data dostępu: 1.03.2019].

http://spisekpisarzy.pl/2016/01/kreatywna-dekonstrukcja-cwiczenie-na-mocniejsze-pioro.html [data dostępu: 3.02.2019].

http://teachmag.com/archives/5539 [data dostępu 1.03.2019].

https://thewritepractice.com/what-is-found-poetry/ [data dostępu: 2.03.2019].

http://tumblr.austinkleon.com/post/15863189174 (tłumaczenie własne) [data dostępu: 3.02.2019].

http://www.centropa.org/node/60518 [data dostępu: 8.03.2019].

https://www.facinghistory.org/resource-library/teaching-strategies/found-poems [data dostępu:

28.02.2019]. 
https://www.facinghistory.org/sites/default/files/Creating_a_Found_Poem_1.pdf [data dostępu: 3.03.2019]

http://www.foundpoetryreview.com/ [data dostępu 2.03.2019].

https://www.nytimes.com/interactive/2014/multimedia/blackout-poetry.html?mcubz=3\&_r $=0$ [data dostępu: 2.03.2019].

https://www.powerpoetry.org/actions/5-tips-creating-blackout-poetry [data dostępu: 3.03.2019].

https://www.scholastic.com/teachers/blog-posts/john-depasquale/blackout-poetry/ [data dostępu: 1.03.2019]. 